\title{
New riodinids from the Central Brazilian plateau (Lepidoptera, Riodinidae)
}

\section{Curtis J. Callaghan ${ }^{1}$}

\begin{abstract}
Eight new riodinid taxa from the Central Brazilian plateau are described as follows: Euselasia thucydides truncata ssp. n.; Mesosemia pardalis sp. n.; Eurybia rubeolata planaltensis ssp. n. Symmachia basilissa paracatuensis ssp. n.; Audre drucei nordensis ssp. n.; Audre caracensis sp. n.; Nymphidium caricae goiacensis ssp. n.; Thisbe rupestre sp. n. The food plant of Audre caracensis is recorded as a Myrtaceae. Notes are included on the habits, habitats and range of each taxon.

KEY WORDS. Riodinidae, taxonomy, Brazil, Argentina
\end{abstract}

The highlands constituting the Brazilian shield are one of the most prominent geographical features of Brazil. Lying between 600 and 1300 meters above sea level, the Planalto forms the headwaters of four of the principal river basins in Brazil. To the northeast drains the Rio São Francisco. To the north, two important tributaries of the Amazon River, the Rio Tocantins and the Rio Araguaia, have their headwaters in the Planalto, and to the south is the drainage of the Rio Paraná that empties into the Rio Plate. The butterflies from the Planalto thus reflect the faunistic composition of all of these diverse regions and contain endemic taxa as well.

The last study published exclusively on Planalto butterflies consisted of two articles by BROWN \& MIELKE (1967a,b). In these, a list of butterflies was presented with notes on localities and dates of capture. The present article is the first of a series for the purpose of reviewing the species of the family Riodinidae found on the Planalto. Eight new Planalto riodinids are described, with notes on their taxonomic relationships, habits and habitats. The material examined was principally from the collections of the author and Dr. Keith S. Brown Jr. (CJC). In addition, the collections at the Museu Nacional, Rio de Janeiro (MNRJ), the Departamento de Zoologia, Universidade de Paraná (DZUP), and the Departamento de Zoologia of the Universidade de São Paulo (MZSP) were consulted.

\section{Euselasia thucydides truncata ssp. $\mathbf{n}$.}

Figs 21-22

Description. Male. Forewing length of holotype $16.2 \mathrm{~mm}$, material examined between 14 and $18 \mathrm{~mm}(\mathrm{n}=6)$. Forewing triangular with rounded apex, hindwing narrows to a point at anal angle. Dorsal wing ground color dark brown; forewing with light yellow - orange discal spot which reaches from near the inner margin to M3 below the discal cell, with scattered yellow scaling extending to the base. Hindwing with irregular yellow - orange patch in discal area extending from M1

Avenida Suba 130-25, Casa 6, Bogotá, Colombia. 


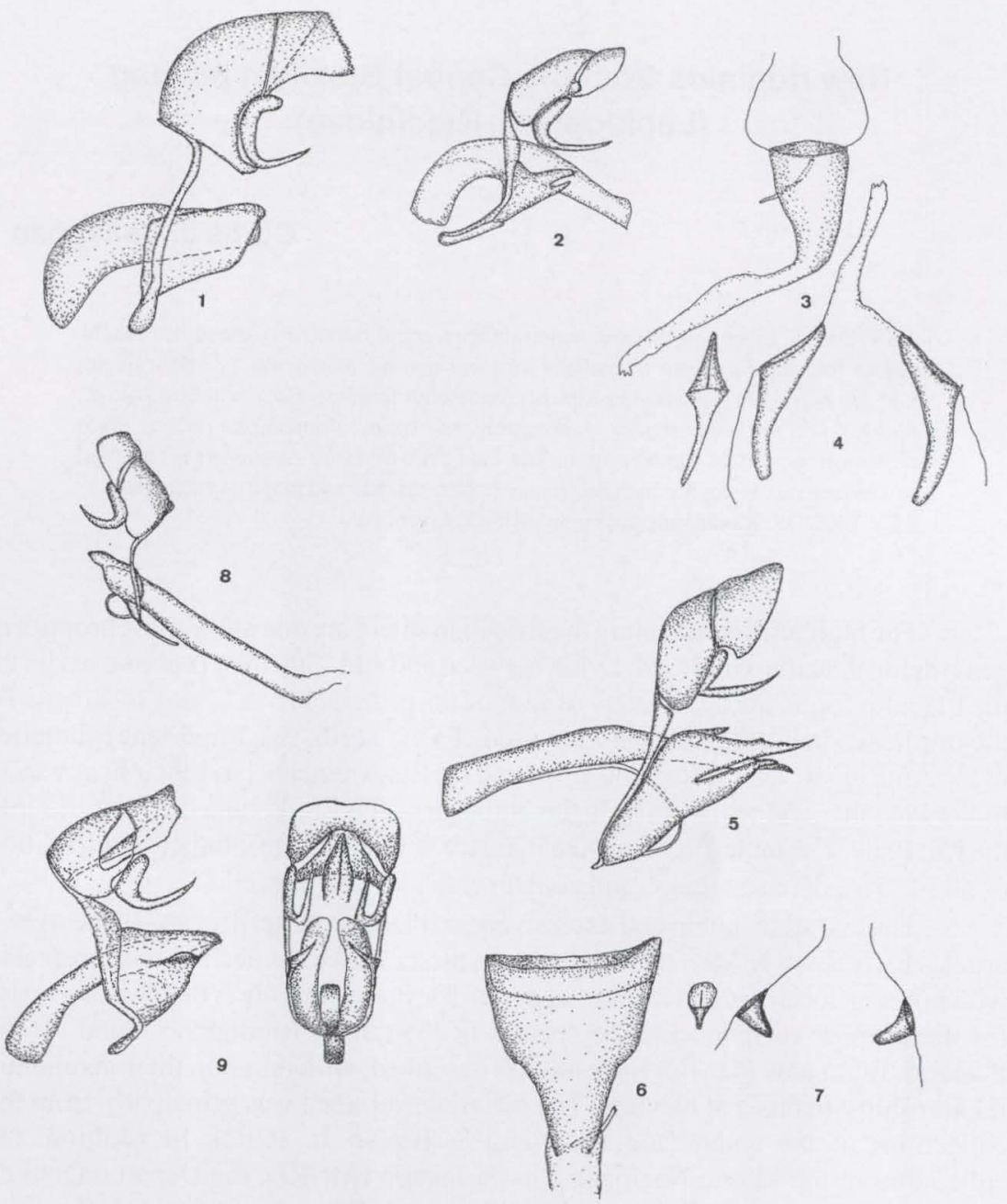

Figs 1-9. (1) Euselasia thucydides truncata, male genitalia; (2) Mesosemia pardalis, male genitalia; (3-4) M. pardalis, female: (3) ostium bursae; (4) corpus bursae and signa; (5-7) Eurybia rubeolata planaltensis: (5) male genitalia; (6) female ostium bursae; (7) female corpus bursae and signa; (8) Symmachia basilissa paracatuensis, male genitalia; (9) Thisbe rupestre male genitalia, lateral and caudal views.

below the discal cell nearly to the base and inner margin. Ventral surface ground color grey with pinkish tone and slightly wavy sub median and median lines, with a postmedian black spot on the inner margin of the forewing and a row of tiny marginal spots between the veins on both wings.

Male genitalia (Fig. 1). With uncus squared, serrate caudad; vinculum narrow, very slightly broader in middle, saccus flat, broad; valvae short, blunt, tips curved inwards; aedeagus with blunt tip.

Female. Unknown. 
Types. Holotype male with label: "BRAzIL, DF, Parque Zoológico, Brasilia 3-II-1967 Keith Brown Jr", with a yellow genitalia label \# 513. Paratypes: 1 male, same data as holotype; 2 male, MG, km 68 Curvelo-Diamantina, 30.IV.1975 (CJC); 1 male, São Paulo, Anhembi (Fazenda Barreira Rica), São Paulo 600 m, 2.VII.1975 (CJC); 1 male, Distrito Federal, Itiquira, 19.X.1970 (CJC). The holotype is deposited in the Museu Nacional, Rio de Janeiro, Brazil.

Etymology. The name refers to the truncated hindwing.

Diagnosis. STICHEL (1925) described Euselasia thucydides mutica from "Paracatú", Minas Gerais. Examination of the type at the Humboldt Museum (Berlin) and the O.D (STICHEL 1926) suggests that this taxon is within the range of variation of nominate $E$. thucydides. The type locality of $E$. $t$. mutica needs verification as the vegetation is typical of the cerrado and very different from the tropical moist forest habitat where nominate E. thucydides is found.

Euselasia t. truncata differs from the nominate subspecies in the shorter, more truncated tails on the hindwing and the more extensive, paler yellow - orange scaling on the forewing.

Distribution and habits. Nominate E. t. thucydides ranges in eastern Brazil from Santa Catarina to Bahia and the Zona do Mato in eastern Minas Gerais, and E. t. truncata through the central Planalto in Goiás south east to the Serra do Cipó and to north central São Paulo. Males perch during the early morning (700-800 hours) on sunlit margins of gallery forests, resting under leaves about a meter above the ground with wings folded. They fly rapidly, chasing each other about until returning to their perching spots. Rare.

\section{Mesosemia pardalis sp. $\mathbf{n}$. \\ Figs 23-25}

Description. Male. Forewing length of holotype $20 \mathrm{~mm}$. Dorsal surface ground color dark brown. Forewing with a postmedian white crescent shaped band extending from $1 \mathrm{~mm}$ below costa to cell $\mathrm{Cu} 1-\mathrm{Cu} 2$, maximum width $3 \mathrm{~mm}$ tapering at both ends; black ocellus at end of discal cell containing three white dots and bordered distad and basad by a faint, curved black line; fringe dark brown. Hindwing with a white $1 \mathrm{~mm}$ wide postmedian band tapering from costa to inner margin, infused with dark brown scaling below $\mathrm{Cul}$; basad two faint, wavy, parallel median lines. Ventral surface ground color lighter with same markings as dorsal surface; hindwing with a small black spot at end of discal cell containing two tiny white dots.

Eyes black; head, thorax and abdomen dark brown.

Genitalia (Fig. 2). Uncus narrow, slightly bifurcated, tegumen broad with a round process covering lateral terminus of the uncus; vinculum narrow, slightly widened in the middle; saccus broad; valvae bifurcated at tip, gnathos simple with blunt tip.

Female. Forewing length of material examined 19 to $22 \mathrm{~mm}(\mathrm{n}=3)$. Dorsal ground color slightly lighter with same markings as male, forewing band $3.5 \mathrm{~mm}$ at widest, ocellus with circular concentric lines repeated in cell $\mathrm{Cu} 1-\mathrm{Cu} 2$; hindwing band $2 \mathrm{~mm}$ wide tapering to inner margin without infusion of brown scaling. Ventral surface with limbal area dark brown, hindwing discal area lighter with three wavy parallel lines and small cellular black spot bordered distad and basad with white. 


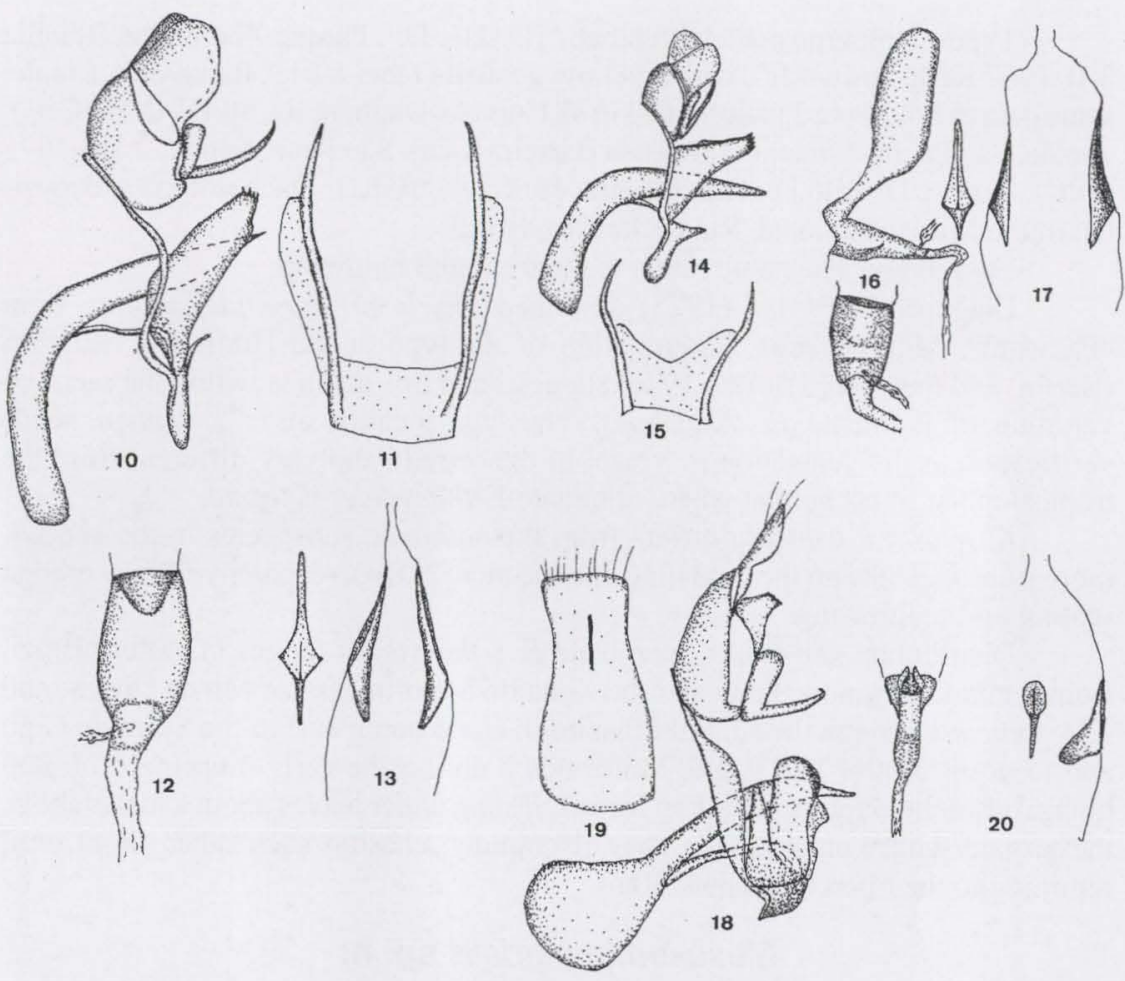

Figs 10-20. (10-13) Audre drucei nordensis: (10) male genitalia; (11) male rami; (12) female ostium bursae; (13) female corpus bursae with signa; (14-17) Audre caracensis: (14) male genitalia; (15) male rami; (16) female ostium bursae; (17) female corpus bursae with asymmetric signa; (18-20) Nymphidium caricae goianensis: (18) male genitalia; (19) male rami; (20) female genitalia.

Genitalia (Figs 3-4). Ostium bursae funnel shaped, ductus seminalis exits dorsad of sinus vaginalis; signa on corpus bursae elongated, curved with blunt tips.

Types. Holotype male with label "BRAzIL Goiás, Anápolis, 1-1936 (Fairchild) (MNRJ)". Paratypes: 1 male, 1 female Belém-Brasilia highway km 47, 19.IV.1973 (CJC); 2 females, Distrito Federal, Parque do Gama, Brasília, 17.V.1969, Keith Brown Jr. leg. (CJC); 1 female, Goiás, Anápolis, XII.1935 Fairchild leg. (MNRJ). The holotype is deposited in the Museu Nacional, Rio de Janeiro, Brazil.

Etymology. The name pardalis refers to the dark color of the butterfly.

Diagnosis. Mesosemia pardalis belongs to the judicialis group -Judicialiformes (STICHEL 1910) -, characterized by postmedian white bands of varying width on both wings and similar genitalia, and is the only Mesosemia of this group flying on the Planalto. Mesosemia pardalis is close to Mesosemia nerine Stichel, 1909, and Mesosemia tenebricosa Hewitson, 1877, from Bolivia and the western Amazon basin respectively, but can be easily separated by the lack of concentric rings around 
the ocellus of the forewing, and the forewing band which is widest in the middle. The male genitalia of $M$. pardalis is narrower and more pointed, and the saccus wider and longer than in either of the other two species. The valvae of $M$. nerine are longer and more deeply bifurcated, and those of $M$. tenebricosa more truncated than $M$. pardalis. These differences and the lack of known intergrades suggests species status for $M$. pardalis.
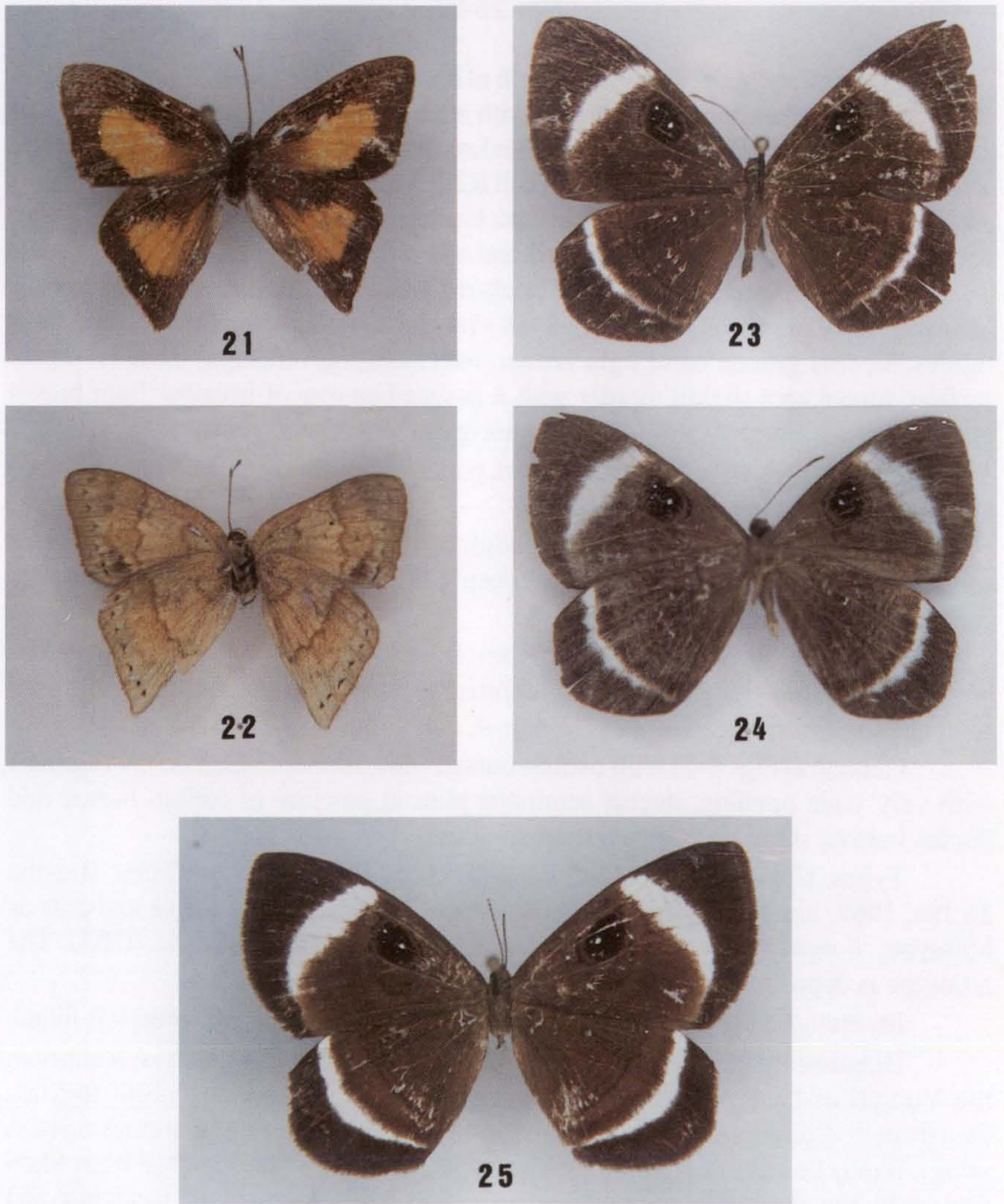

Figs 21-25. (21-22) Euselasia thucydides truncata, holotype male: (21) dorsal; (22) ventral; (23-25) Mesosemia pardalis: (23) holotype male dorsal; (24) holotype male ventral; (25) female dorsal. 
Distribution and Habits. Mesosemia pardalis is a true Planalto endemic. It inhabits the Cabeceira woods and gallery forests along streams from central Goiás to near Uberlândia, Minas Gerais (Keith Brown Jr., pers. com.) where individuals rest with wings outspread under leaves near sunflecks in the deep shady woods in the early afternoon. Rare.

\section{Eurybia rubeolata planaltensis ssp. $\mathbf{n}$.}

Figs 26-29

Description. Male. Forewing length of holotype $25 \mathrm{~mm}$. Dorsal surface ground color and fringe dark brown. Forewing with a faint, black ocellus at the distal end of the discal cell with light orange scaling distad and basad, and a second faint spot directly below in cell $\mathrm{Cu} 2-1 \mathrm{~A}+2 \mathrm{~A}$; white dot in cell R2-R3 and in cell R4-R5; a very faint post median band and a submarginal row of dark brown spots between the veins. Hindwing with a faint black spot in the discal cell and a row of submarginal dark brown spots between the veins surrounded by pale brick-red scaling, which extends basad in cells M2-M3, M3-Cu1, Cu1-Cu2 and Cu2-2A+3A, surrounding dark brown arrowhead figures. Ventral ground color light brown, with markings reflecting those on dorsal surface, limbal area slightly lighter with a postmedian row of irregular light brown markings and a marginal row of faint round spots between the veins.

Eyes shiny blue in life; head brown, palpi yellow, thorax and abdomen brown dorsad, slightly lighter ventrad.

Genitalia (Fig. 5) with uncus slightly bilobed, vinculum long, widened caudad, saccus small, pointed; valvae deeply bifurcated at tip, transtilla projects caudad; aedeagus pointed.

Female. Forewing length 25-26 mm. Dorsal ground color of both wings pale brown, limbal area lighter, markings identical to male; hindwing without brick-red scaling.. Ventral surface identical to dorsal, only lighter.

Genitalia (Figs 6-7) with ostium bursae wide, funnel shaped, sinus vaginalis with very wide opening, ductus seminalis joins at juncture of ostium bursae and ductus bursae; signa on corpus bursae small, short.

Types. Holotype male, with label "BrAzIL: DF, Parque do Gama, Brasilia 26 Jan, 1968, leg. Keith Brown Jr". Paratypes: 2 females, same locale and date as holotype; 1 male, Distrito Federal, Parque do Gama, Brasília, 4.XI (CJC). The holotype is deposited in the Museu Nacional, Rio de Janeiro, Brazil.

Etymology. The name of this subspecies refers to the Planalto where it is found.

Diagnosis. Eurybia rubeolata Stichel, 1910, ranges from its type locality in the Yungas of La Paz, Bolivia, east to central Goiás, Brazil, and north to Meta Department, Colombia. E. r. planaltensis differs in the much paler markings on both wings. It may be separated from Eurybia elvina passercula Stichel, 1915 from Mato Grosso by the absence of the postmedian row of white spots on the forewing, and the elongated arrowhead figures on the hindwing.

Distribution and Habits. E. r. planaltensis is known only from central Goiás where it frequents cabeceira woods, resting under leaves. Rare. 

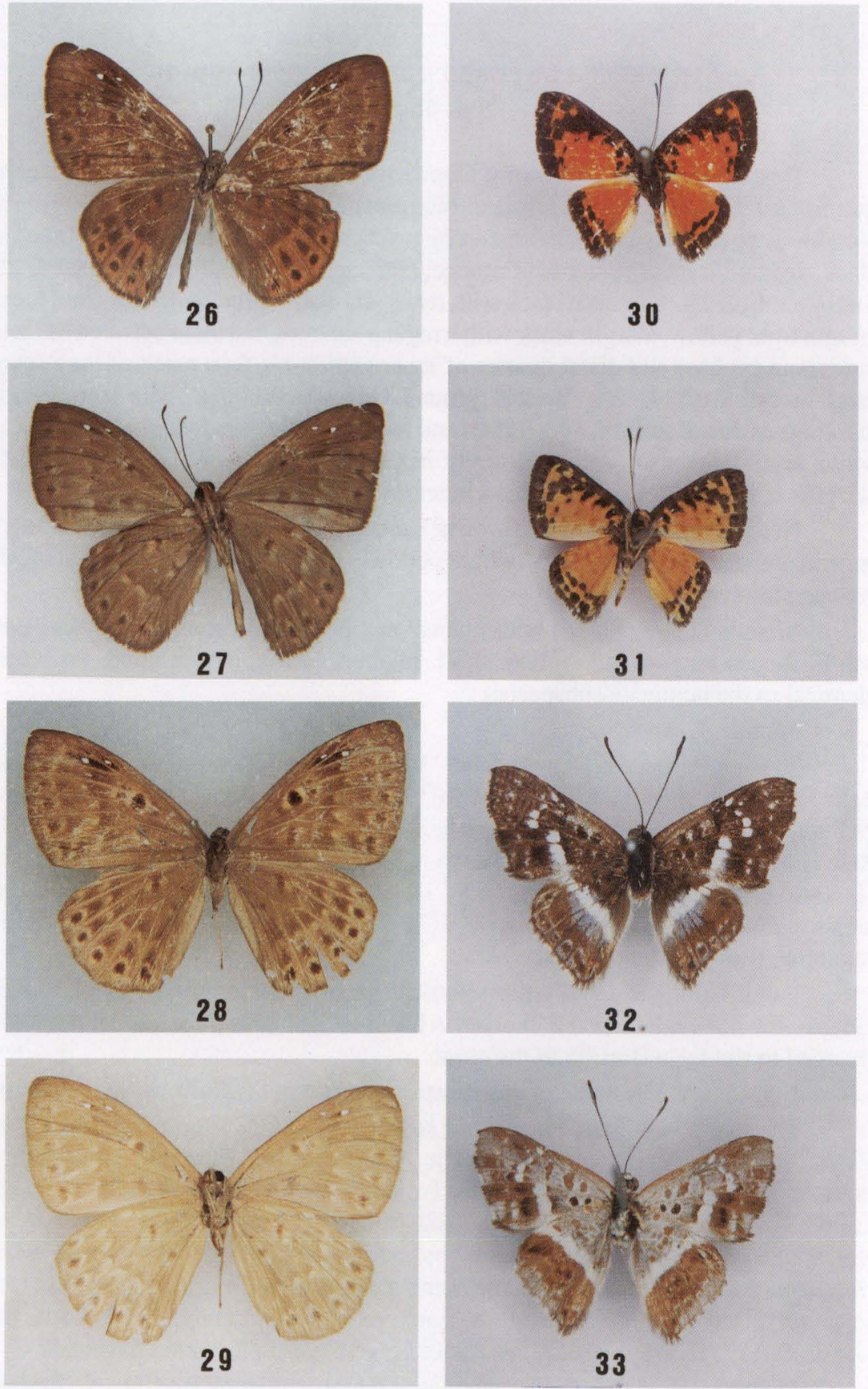

Figs 26-33. (26-29) Eurybia rubeolata planaltensis: (26) holotype male dorsal; (27) holotype male ventral; (28) female dorsal; (29) female ventral; (30-31) Symmachia basilissa paracatuensis, holotype male: (30) dorsal; (31) male ventral; (32-33) Thisbe rupestre holotype male: (32) dorsal; (33) ventral. 


\section{Symmachia basilissa paracatuensis ssp. $\mathbf{n}$.}

Figs $30-31$

Description. Male. Forewing length of holotype $10 \mathrm{~mm}$, range of material examined $9-11 \mathrm{~mm}$. $(\mathrm{n}=13)$. Dorsal surface ground color orange with variable black borders. Forewing costa black, broken by patches of orange scaling; distal margin black, apex with square patches of orange, black spots in limbal area cells M3-Cu1, $\mathrm{Cu} 1-\mathrm{Cu} 2, \mathrm{Cu} 2-1 \mathrm{~A}+2 \mathrm{~A}$; base black with two spots distad. Hindwing costa and inner margin light yellow, margin black with irregular submarginal band between $\mathrm{Ml}$ and inner margin; base and distal quarter of inner margin black; a patch of long scent hairs in cell $\mathrm{Cu} 2-1 \mathrm{~A}+2 \mathrm{~A}$. Ventral ground color light orange with same black markings as dorsal surface, only lighter and more separate; inner margin of forewing white; scent hairs also present ventrally in cell $\mathrm{Cu} 2-1 \mathrm{~A}+2 \mathrm{~A}$. Cilia black on distal margins of both wings, and white on inner margin of hindwing.

Head, thorax and abdomen brown; frons and base of antennae, tegula orange; appendages and abdomen ventrally light yellow; abdomen with orange dorsal bands between the segments.

Male genitalia (Fig. 8) with uncus long, broad; vinculum thin, of uniform width, saccus long, broad; valvae short, pointed, aedeagus very long, tip blunt, identical to the nominate subspecies.

Female. Unknown

Types. Holotype male with label "BRAZIL: Minas Gerais, Paracatú, km 235 Belo Horizonte-Brasilia Hwy, 18 April1973 leg. C. Callaghan", and a yellow genitalia label \# 469. Paratypes: 4 males, M.G., Município de Paracatú, km 590* Belo Horizonte-Brasília hwy. 24.V.1986, Callaghan leg. (CJC); 8 males, M.G., km 500 Belo Horizonte-Brasilia hwy, 16.IV.1973 Callaghan leg. (CJC); 2 males, same locality, 27.XII.1975, Callaghan leg. (CJC). The holotype is deposited in the Museu Nacional, Rio de Janeiro, Brazil.

Note. Until the 1980's the kilometer posts were numbered from Rio de Janeiro, the old capital, to the interior. After Brasilia became the capital, this was changed to run from Brasilia to the coast.

Etymology. The name of this subspecies refers to Paracatú, the type locality.

Diagnosis. Nominate Symmachia basilissa (Bates, 1868) was described from a male labelled "Pará", currently in The Natural History Museum, London, and characterized with solid black margins. Examination of this specimen and another captured in the Serra Dourada South of Goiás Velho (CJC) suggest that this phenotype, typical of lowland Amazonian populations, reaches the Planalto in the west. Symmachia $b$. paracatuensis differs from the nominate subspecies in having the solid black costa and distal margins broken up by patches of orange scaling. The genitalia are identical. HALL \& WILLMOTT (1996) placed this species in the genus Symmachia.

Distribution and habits. Symmachia $b$. paracatuensis inhabits the eastern half of the Planalto from Brasilia to western Minas Gerais. Males congregate on hilltops in the late morning and early afternoon, resting beneath leaves 1 to $3 \mathrm{~m}$. above the ground with wings flat. Common where found. 


\section{Thisbe rupestre sp. $\mathbf{n}$.}

Figs $32-33$

Description. Male. Forewing length of holotype $13.5 \mathrm{~mm}$. Forewing angled above M3, hindwing distal margin straight to rounded point at anal angle, ground color brown with white and blue markings. Dorsal forewing with submarginal row of small white spots between veins, postmedian row of five white spots from cell R3-R4 to cell $\mathrm{Cu} 1-\mathrm{Cu} 2$, then a postmedian white band from $\mathrm{Cu} 2$ to inner margin, bordered distad by blue scaling; discal cell with two black spots and a line at end of cell, separated by white scaling; below these in cell $\mathrm{Cu} 2-1 \mathrm{~A}+2 \mathrm{~A}$ two similar spots with white/blue scaling. Hindwing with row of submarginal brown spots between veins outlined in blue and two faint subapical brown spots; a $1.5 \mathrm{~mm}$ wide median band contiguous with forewing band, and scattered blue scaling distad between $\mathrm{Ml}$ and $2 \mathrm{~A}$ and basad between M2 and Cul; some faint orange scaling at anal angle. Ventral forewing light brown infused with blue scaling, pattern same as dorsal, spots in cell light brown, the two below black. Hindwing limbal area light brown with margin infused by blue scales; basad of median white band infused with white scales are three faint irregular light brown spots in discal cell, two above and two below. Fringe white and brown.

Head, thorax and abdomen brown dorsad, head black with long scales on frons, orbit and palpi white; antennae with white rings at segments, vertex with two scaly "horns" caudad of antennae; thorax ventrally and appendages white.

Genitalia (Fig. 9). With tegumen elongated, uncus broad, not lobed; vinculum wider in middle, saccus narrow; valvae triangular shaped with lateral flanges, tips blunt.

Female. Unknown.

Types. Holotype male with label "BrAzIL: GO, Cavalcante, coll E.May/ex col.Gagarin", with a genitalia label \# 499. Paratypes 2 males, M.G. km 68, Curvelo-Diamatina, Serra Espinhaço, O. Mielke leg. The holotype and paratypes are in the collection of the Departamento de Zoologia, Universidade Federal de Paraná, Curitiba. (DZUP).

Etymology. The name refers to the high mountain meadows with their exotic plant life where Dr. Olaf Mielke rediscovered this species.

Diagnosis. The venation, wing shape and genitalia place this species in the genus Thisbe. (J. Hall, pers. com.).

Distribution and habits. This butterfly is found rarely from the Serra Espinhaço, Minas Gerais, west to central Goiás in November/December at the beginning of the rains. It flies in the open cerrado and "campos repustres" grasslands, resting on upper leaf surfaces with wings spread. (O. Mielke, pers. comm.).

\section{Audre drucei nordensis ssp. $\mathbf{n}$.}

Figs 34-37

Description. Male. Forewing length of holotype $17.5 \mathrm{~mm}$, range of material examined 16 to $22 \mathrm{~mm}$. $(\mathrm{n}=8)$. Dorsal surface brown with orange markings. Forewing with row of submarginal irregular orange dots between the veins, smaller marginal dots in cells R4-M1, M3-Cul and $\mathrm{Cu} 2-1 \mathrm{~A}+2 \mathrm{~A}$; basad of these a third row 
of large orange dots forming a "question mark", broken at vein Cul; discal cell orange containing two black dots, a line at the end of the cell and two identical dots below in cell $\mathrm{Cu} 2-1 \mathrm{~A}+2 \mathrm{~A}$; cilia brown with white marks between the veins. Hindwing light brown-orange with row of marginal black spots between the veins; basad of these is an irregular brown patch between the costa and $\mathrm{Cu} 2$; costa brown with three faint brown lines invading the discal cell; hindwing covered with long androconal hairs. Ventral forewing reflects markings on dorsal surface, but lighter; apex brown with white maculation; anal cell white; rest of wing light orange with black maculation. Hindwing with veins outlined in light brown; row of eight submarginal spots outlined variably in white between the veins, the first three and last two black; limbal area light brown, discal area white with circular black marks within, above and below the discal cell; cilia brown with white marks between the veins.

Thorax, abdomen light brown dorsad, white ventrad, head, palpi white, eyes brown, probosis greatly enlarged at base.

Genitalia (Fig. 10). With uncus deeply bifurcated into two widely separated lobes, vinculum thin, saccus long, cylindrical with caudal support for rami; valvae long, wide, stepped at end with toothed tips, aedeagus with pointed tip, pedicel squared; rami (Fig. 11) bifurcated into two long pencil-like projections.

Female. Forewing length 18 to $22 \mathrm{~mm}(\mathrm{n}=5)$. Dorsal ground color lighter shade than male, but with the same maculation.

Gentalia (Figs 12-13) with ostium bursae tube-like, point of origin of ductus seminalis is the base of the ostium bursae; corpus bursae with two large, pointed signa.

Types. Holotype male with label "Argentina, Prov. Salta, $3 \mathrm{~km}$ SE Pichanal, 300 m. 13-XI-1973 (R. Eisele)”. Paratypes: 5 males, 5 females, same locality and date as holotype; 3 males, same locality, 5.XI.1968; 3 males, same locality, 29.XI.1968; 5 males, same locality, 26.XI.1968; 2 males, same locality, 31.XI.1968: Prov. Jujuy, 2.XI.1987; Brazil, Goiás, 1 male, Piracanjuba, 85 km South of Goiânia 600-700 m, 2.XI.1969 (CJC). The holotype is deposited in the Museu Nacional, Rio de Janeiro, Brazil.

Etymology. The name refers to the northern range of this subspecies relative to the nominate subspecies.

Diagnosis. Audre drucei drucei (Giacomelli, 1914) was described from Chumbicha in southern Catamarca Province, Argentina. Additional specimens in the author's collection suggests the range of the nominate subspecies is from Entre Rios and Buenos Aires Provinces west to the foothills of the Andes, probably intergrading with subspecies nordensis in Jujuy Province. Audre d. nordensis differs from the nominate subspecies in the lighter, yellow ground color and the absence of the white markings on the forewings. The genitalia are identical.

Despite the distance from the Salta population, the Piracanjuba specimen is practically identical to the type, differing only in having a slightly narrower forewing band. This suggests that there may be other as yet undiscovered populations between Argentina and Minas Gerais, Brazil. 

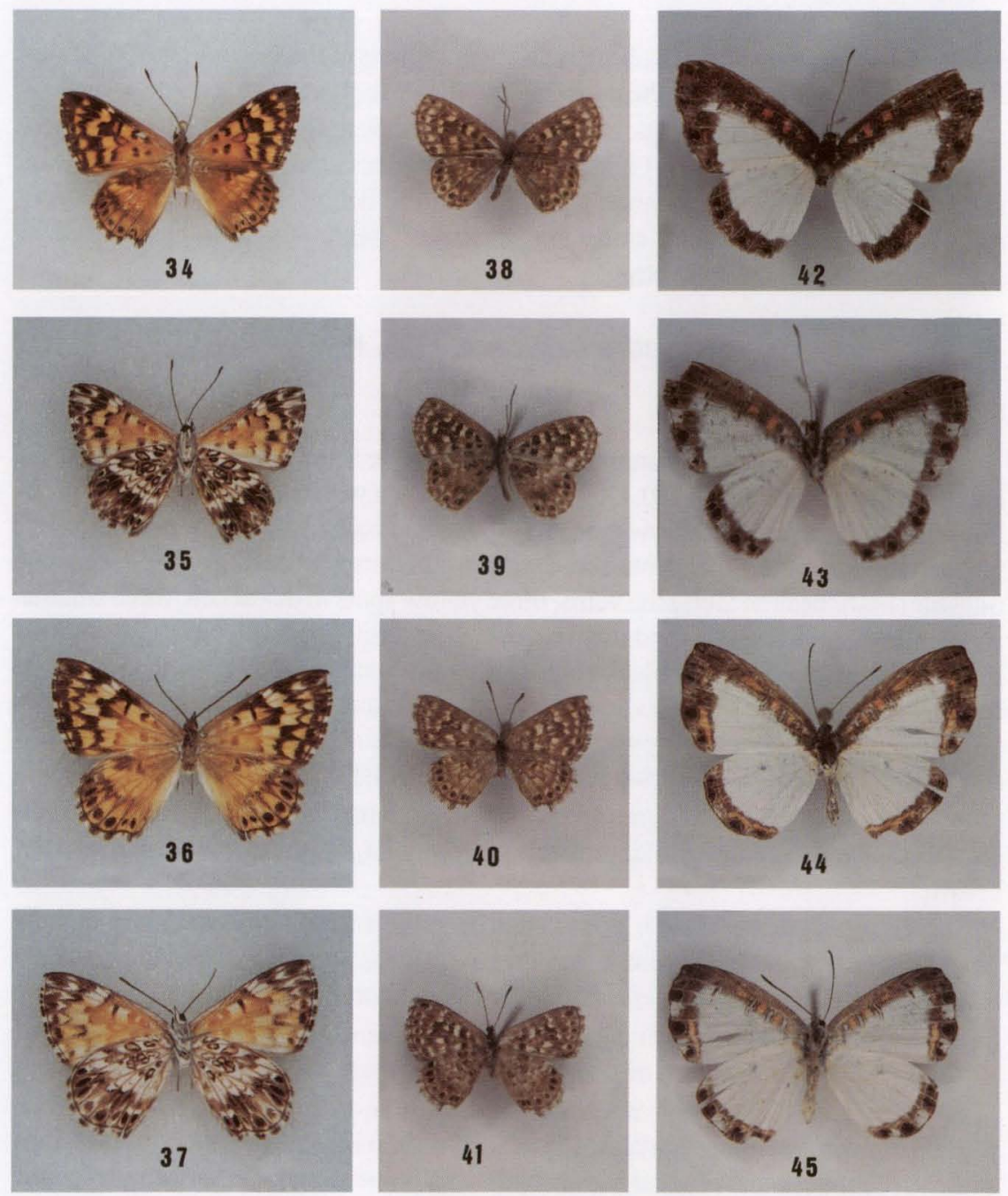

Figs 34-45. (34-37) Audre drucei nordensis: (34) holotype male, dorsal; (35) holotype male ventral; (36) female dorsal; (37) female ventral; (38-41) Audre caracensis: (38) holotype male dorsal; (39) holotype male ventral; (40) female dorsal; (41) female ventral; (42-45) Nymphidium caricae goiacensis: (42) male dorsal; (43) male ventral; (44) female dorsal; (45) female ventral.

This species may be confused with Audre aurinia (Hewitson, 1863) and its subspecies Audre aurinia incana (Stichel, 1910). Audre aurinia was described from "Amazonas" and ranges from La Macarena, Meta, Colombia, through the northern Amazon basin, flying in open "campos". Subspecies A. a. incana was described from Peru, differing from $A$. aurinia in the pattern of the ventral hindwing. It ranges from Peru to the Brazilian Planalto, where it is sympatric with $A$. d. nordensis, suggesting it is a distinct species. 
All these taxa are univoltine with flight periods at the beginning of the rains from September/October in the north to November in Argentina.

Distribution and Habits. Subspecies nordensis ranges from Salta Province, Argentina north to southern Goiás. The Piracanjuba locality is similar to that of southern São Paulo, with bamboo growth. (Keith S. Brown Jr., pers. com.) According to Robert Eisele, pers. com., the butterfly inhabits dry thornbush scrub in Argentina. Rare in the Planalto.

\section{Audre caracensis sp. $\mathrm{n}$.}

Figs $38-41$

Description. Male. Forewing length holotype $9 \mathrm{~mm}$, the range of material examined 8 to $11 \mathrm{~mm}(\mathrm{n}=10)$. Dorsal surface brown with light yellow maculation. Forewing with a row of yellow marginal spots, and basad of these a second row of larger yellow submarginal spots between veins; yellow postmedian band in form of question mark broken along the veins, three yellow spots in discal cell, three smaller spots above along costa, and two below; cilia brown. Hindwing veins lightly outlined in brown; a row of black submarginal spots surrounded by yellow scaling, discal area brown with small, variable yellow spots, and two darker indistinct spots in discal cell; cilia light brown. Ventral ground color brown with dirty white maculation, pattern as on dorsal surface, but more distinct.

Head, thorax and abdomen dark brown; antennae with white scaling on each segment, frons and palpi white, probosis greatly enlarged at base; appendages light brown.

Genitalia (Figs 14-15). With uncus deeply bifurcated, lobes widely separated; vinculum thin, saccus long, tubular, with caudad support for rami; valvae triangular, tips round with teeth; rami bifurcated, short.

Female. Forewing average length $11.4 \mathrm{~mm}$, range of material examined 9 to $12 \mathrm{~mm}(\mathrm{n}=7)$. Wing pattern of female identical to male, with wings more rounded.

Genitalia (Figs 16-17) with ostium bursae tube-like, sclerotized around sinus vaginalis, ductus seminalis attached to base of ostium bursae; ostium bursae at right angle to papillae anales; corpus bursae with long, pointed signa. In some individuals, signa are asymmetrical (Fig. 17).

Types. Holotype with label "BrazIL: M.G., Serra de Caraça, 1500 m., 22-iv-1975 leg.C.Callaghan" and a yellow genitalia label \#473. Paratypes: 4 males, 5 females, same locality and date as holotype; 2 males, Distrito Federal, Brasília Country Club, 15.V.1977 (CJC); 1 male, M.G. Motel Clube km 418 Rio-Belo Horizonte, Serra da Moeda, Callaghan leg.; 2 males, Distrito Federal, Parque Mun. do Gama, 17.V.1969 Keith Brown Jr. leg. (CJC). The type is deposited in the Museu Nacional, Rio de Janeiro, Brazil.

Etymology. This species is named after the type locality.

Diagnosis. This tiny butterfly is easily separated from all Planalto Audre by its size and dark brown ground color. It is distinguished from A. hubrichi, with which it flies in Brasilia, by the brown instead of orange ground color on the dorsal surface 
and distinct pattern on the ventral surface. The male genitalia differ from $A$. hubrichi in the straighter falces, shorter pedicel, and the two prongs of rami that are not fused at the base. There is considerable individual variation within populations of this species, particularly the ground color on the dorsal surface, which may have greater or lesser infusions of orange scaling.

Distribution and habits. The type locality is Caraça, $1500 \mathrm{~m}$ in the Serra de Caraça, Minas Gerais, at the southern end of the Serra de Espinhaço range. From there, the butterfly ranges to the hills south of Belo Horizonte, then across the Planalto to Brasília. It can be common in grass bog meadows near seeps. The butterflies fly near the ground and rest on grass stems with wings folded. At Caraça, I observed a female ovipositing on a low shrub growing on the edge of a bog, later identified as belonging to the family Myrtaceae.

\section{Nymphidium caricae goiacensis ssp. $\mathbf{n}$.}

Figs $42-45$

Description. Male. Forewing length of holotype $17 \mathrm{~mm}$, range of material examined 17 to $19 \mathrm{~mm}(\mathrm{n}=4)$. Dorsal surface white with dark brown borders. Forewing costa dark brown to below cell, three orange red dots in discal cell and a variable, indistinct orange red line distad of cell; submargin dark brown with marginal crescent spots outlined in blue between the veins, and basad of these an indistinct, broken orange red line; white triangular area pinched along vein $\mathrm{Cul}$ by the last of four subapical black marks. Hindwing margin dark brown, with black crescent spots outlined in blue between the veins and a broken, indistinct thin red line distad of these; base dark brown. Ventral forewing with same pattern as dorsal; three orange spots in discal cell separated by two black elongated, oval figures, three short lines at end of cell and four subapical black marks. Hindwing with same maculation as dorsal, but lighter.

Head and thorax black, abdomen and appendages white; antennae ringed with white between segments, frons, labial palpi white.

Genitalia (Figs 18-19). Uncus bilobed, prominant socci connecting uncus to gnathos; transtilla slightly broader in middle, saccus prominent; valvae truncated, turned inwards with sclerotized tips, base of transtilla with dark spot; aedeagus pointed; rami tip squared with sclerotized flange.

Female (Figs 44-45). Same colors and pattern as male; wings more rounded; apex of white triangular area of forewing not as pinched as in male.

Genitalia (Fig. 20). With ostium bursae tube-like with a small sclerotized flange on either side of sinus vaginalis, ductus seminalis broad, attached at juncture of ostium and ductus bursae; corpus bursae with two small blunt signa.

Types. Holotype with label "BRAZIL: Goiás, Serra Dourada, 23/26-IV-1973 leg. C. Callaghan." Paratypes: 1 male, Mato Grosso, Alto Araguaia, Rondonópolis; 3 females, Goiás, nr. Jussara, Cuiabá-Goiás hwy, Callaghan leg.; 1 male, km 156 Goiás-Iporá Hwy, 22.IV.1973, Callaghan leg.; 1 male, Mato Grosso, Barra dos Bugres, 15.I.1977, Keith Brown Jr. leg. The holotype is deposited in the Museu Nacional, Rio de Janeiro, Brazil. 
Etymology. This subspecies is named for the Brazilian state in which it was discovered.

Diagnosis. Nymphidium c. goiacensis represents the extreme southeastern range of $N$. caricae Linn. It differs from the nominate subspecies from the Amazon lowlands in the much thinner and broken orange bands on the costa and margins. The extent of the orange on the margins can vary considerably between individuals. It apparently intergrades with $N$. caricae in western Mato Grosso. The genitalia are identical to nominate subspecies.

Distribution and habits. N. c. goiacensis ranges from central Goiás west to Mato Grosso. It inhabits gallery forests where males and sometimes females perch inside the sunlit edge of the woods from noon to about 1500 . They rest on the ventral leaf surfaces with wings open. Locally common.

ACKNOWLEDGEMENTS. The author wishes to thank Dr. Alexandre Soares of the Museu Nacional, Rio de Janeiro, and Dr. Olaf Mielke at the Departamento de Zoologia da Universidade Federal de Paraná, Curitiba for access to the collections under their care and for the loan of material, and Dr. Wolfram Mey (ZMHU) for allowing me to study and photograph types. To Dr. Keith S. Brown Jr. and Dr. Jason Hall my thanks for helpful comments on the paper.

\section{REFERENCES}

Brown, K.S. \& O. MifLKE. 1967a. Lepidoptera of the central Brazilian plateau. I. Preliminary list of Rhopalocera: Introduction, Nymphalidae, Libytheidae. Jour. Lepidopt. Soc. 21 (2): 77-106.

. 1967b. Lepidoptera of the central Brazilian plateau II. Preliminary list of Rhopalocera (continued): Lycaenidae, Pieridae, Papilionidae, Hesperidae. Jour. Lepidopt. Soc. 21 (3): 145-168. HALL, J.P. \& K.R. WILLMOTT. 1996. Systematics of the riodinid tribe Symmachiini, with the description of a new genus and five new species from Ecuador, Venezuela and Brazil (Lepidoptera: Riodinidae) Lambillonea 96 (4): 637-660.

SticheI., H. 1910. Fam. Riodinidae. Allgemeines. Subfam. Riodininae. Genera Insectorum 112A, p. $1-238$.

1911. Fam. Riodinidae. Allgemeines. Subfam. Riodininae. Genera Insectorum 112B, p. $239-452$.

1910. Vorarbeiten zu einer revision der Riodinidae Grote (Erycinidae, Swains.) (Lep. Rhop.)

Berl. ent. Z. 55: 9-103.

1926. Beiträge sur Kenntnis der Riodinidenfauna Südamerikas. Z. wiss. Ins-Biol. 19: 260.

Recebido em 28.IX.2000; aceito em 19.VII.2001. 